2011-01-01

\title{
Size matters: the late payment problem
}

\section{Paul, S}

http://hdl.handle.net/10026.1/11331

10.1108/14626001111179776

Journal of Small Business and Enterprise Development

Emerald

All content in PEARL is protected by copyright law. Author manuscripts are made available in accordance with publisher policies. Please cite only the published version using the details provided on the item record or document. In the absence of an open licence (e.g. Creative Commons), permissions for further reuse of content should be sought from the publisher or author. 


\section{Journal of Small Business and Enterprise Development Emerald Article: Size matters: the late payment problem Salima Y. Paul, Rebecca Boden}

\section{Article information:}

To cite this document: Salima Y. Paul, Rebecca Boden, (2011),"Size matters: the late payment problem", Journal of Small Business and Enterprise Development, Vol. 18 Iss: 4 pp. 732 - 747

Permanent link to this document: http://dx.doi.org/10.1108/14626001111179776

Downloaded on: 13-02-2013

References: This document contains references to 63 other documents

Citations: This document has been cited by 1 other documents

To copy this document: permissions@emeraldinsight.com

This document has been downloaded 859 times since 2011. *

\section{Users who downloaded this Article also downloaded: *}

Salima Y. Paul, Rebecca Boden, (2011),"Size matters: the late payment problem", Journal of Small Business and Enterprise Development, Vol. 18 Iss: 4 pp. 732 - 747

http://dx.doi.org/10.1108/14626001111179776

Salima Y. Paul, Rebecca Boden, (2011),"Size matters: the late payment problem", Journal of Small Business and Enterprise Development, Vol. 18 Iss: 4 pp. 732 - 747

http://dx.doi.org/10.1108/14626001111179776

Salima Y. Paul, Rebecca Boden, (2011),"Size matters: the late payment problem", Journal of Small Business and Enterprise Development, Vol. 18 Iss: 4 pp. 732 - 747

$\underline{\mathrm{http}: / / \mathrm{dx} \text {.doi.org/10.1108/14626001111179776 }}$

Access to this document was granted through an Emerald subscription provided by UNIVERSITY OF MALAYA

\section{For Authors:}

If you would like to write for this, or any other Emerald publication, then please use our Emerald for Authors service. Information about how to choose which publication to write for and submission guidelines are available for all. Please visit www.emeraldinsight.com/authors for more information.

\section{About Emerald www.emeraldinsight.com}

With over forty years' experience, Emerald Group Publishing is a leading independent publisher of global research with impact in business, society, public policy and education. In total, Emerald publishes over 275 journals and more than 130 book series, as well as an extensive range of online products and services. Emerald is both COUNTER 3 and TRANSFER compliant. The organization is a partner of the Committee on Publication Ethics (COPE) and also works with Portico and the LOCKSS initiative for digital archive preservation. 


\section{JSBED}

18,4

732

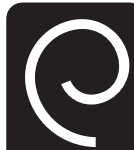

Emerald

Journal of Small Business and Enterprise Development

Vol. 18 No. 4, 2011

pp. $732-747$

(C) Emerald Group Publishing Limited 1462-6004

DOI $10.1108 / 14626001111179776$

\section{Size matters: the late payment problem}

\author{
Salima Y. Paul
}

Bristol Business School, University of the West of England, Bristol, UK, and

Rebecca Boden

Roehampton Business School, Roehampton University, London, UK

\begin{abstract}
Purpose - The supply of trade credit by small- to medium-sized enterprises (SMEs) is the product of both customer demand and the possibility of strategic advantage, but is subject to risk. In the current financial climate the demand for trade credit may be heightened, leading to further increased risk. This paper seeks to evaluate current risk mitigation measures in the UK and considers how these might be improved.
\end{abstract}

Design/methodology/approach - The supply of and demand for trade credit and the inherent risks are explained by reference to the literature. Then, using both the academic and grey literature and data from a large-scale questionnaire, the paper highlights the limitations of both regulatory and management approaches to mitigate the risks in the context of UK SMEs. Finally, the paper considers the prospects for improved management.

Findings - Trade credit may be a product of market demand or a desire to extract strategic advantage. Both regulatory measures and internal management regimes have failed to mitigate risks in the UK for SMEs extending trade credit.

Practical implications - The paper concludes that current UK regulatory regimes are unlikely to prove effective and that better management of trade credit may be imperilled by the power imbalances between SMEs and larger firms. The paper suggests areas for the improvement of trade credit management under the headings of policies, people, processes and practices within SMEs.

Originality/value - The paper demonstrates why, despite the risk, UK SMEs offer trade credit and consider how those risks might be mitigated.

Keywords Trade credit, Late payment, Small to medium-sized enterprises, Regulation, Management, United Kingdom, Financial risk

Paper type Research paper

\section{Introduction}

Working capital management is a crucial factor in individual firm performance and macroeconomically - as the current turmoil in the world's financial markets illustrates (Paul and Boden, 2008). Small and medium enterprises are, by virtue of their size, generally exposed to greater risk from this quarter, making effective control of working capital critical to them (Peel and Wilson, 1996; Kargar and Blumenthal, 1994). Given the economic importance of SMEs in many countries, these firms' working capital management practices may have repercussions well beyond the boundaries of the firm.

Working capital generally comprises a cycle of four principal elements: creditors, stock, trade debtors and incoming cash. Trade debtors are a key in this cash conversion cycle; Wilson (2008) reports evidence that working capital management and late payment problems are a primary cause of small business failure. Whilst firms may have sound business reasons for granting trade credit (Paul and Boden, 2008), the 
time lag between sales and payment may give birth to late payment delinquency or default risks in the form of bad debts. In a study of 1,200 small businesses, Chittenden and Bragg (1997) found that shortening the timescale of the trade credit cycle resulted in improvements in cashflow in the short-term and helped to optimise working capital in the medium-term.

Late payment of trade debts is often associated with the relative power positions of suppliers and customers (especially where the customer is in a monopolistic or oligopolistic position), the competitiveness of markets, disruption associated with changes in payment technologies and customer concentration (Paul and Wilson, 2006). Paul and Wilson (2006) reported that seasonal demand (which may make suppliers less risk-averse as they attempt to shift stock), poor use of credit scoring information (for instance, the US sub-prime mortgage market prior to 2008), capital rationing by banks and financial distress can all contribute to heightened delinquency and default risks.

Trade credit is a prominent part of the UK trading environment, where at least 80 per cent of business-to-business transactions are on credit. British SMEs are currently owed in the order of $£ 26$ billion by their customers (Manager, 2009), making trade debtors one of the biggest and possibly riskiest assets UK firms are likely to have (Paul and Wilson, 2006; Peel et al., 2000; Pike et al., 1998). Indeed, Wilson (2008) reports that "stocks and flows of trade credit are typically twice the size of those for bank creditc (Wilson, 2008, p. 20) and finds that in 2006 limited companies' debtors exceeded $£ 53$ billion, constituting up to 45 per cent of their total assets (65 per cent of current assets). Our data, presented in this paper, shows that just over 91 per cent of respondents sell 80-100 per cent of their goods on credit. In a study of SMEs, Wilson et al. (1996) found that 96 per cent of sales were on credit, but that less than 50 per cent of invoices were paid on time. Almost a decade later, the payment periods continue to lengthen and over half of UK SMEs claim that payment time has worsened (CMRC, 2006). If debtors do not pay on time, companies may find the cost of financing, monitoring, chasing, collecting or writing off bad debts unaffordable (Paul, 2004).

In time of recession "small businesses bear the brunt of the credit squeeze" and "there is a clear relationship between late payment and the rate of insolvency and bankruptcy" (Wilson, 2008, pp. 7-8). In the current period of financial distress, companies, especially small ones, may have to offer even more generous credit terms to win business, thus further increasing their risk exposure.

Investigating the relationship between late payers and firm size, Peel et al. (2000) found large firms to be the worst offenders. Pike and Cheng (2001) report a strong correlation between late payment and size, with smaller firms experiencing the longest delays. The European Commission (Europa, 2009) reports that "SMEs are owed twice as much trade credit as they themselves owe to large businesses. The balance is an interest-free loan of $£ 20$ billion, which SMEs grant - or rather, are forced to grant - to larger businesses". A survey conducted by Barclays (Bizhelp, available at: www. bizhelp24.com/news/apr-08-late-payment-2008-tips-211.php; accessed 1 December, 2009) reveals that UK SMEs "were owed a staggering $£ 8.3$ billion at the end of February 2008, due to late payment" and that the time spent chasing late payers constituted "more than four million wasted working hours or 544,640 wasted working days". Research by Experian, a UK credit rating agency, on 435,000 companies in 2007, found that the late payment problem had hit a new high with large companies "now taking 81.5 days to pay their bills (against 78.5 in 2003), 21.2 days more than small 
JSBED

18,4

734 companies". Similarly, the Forum of Private Business (2008) argues that "it seems to be almost endemic that the SMEs will have to wait for large customers to pay them" and reports that 88 per cent of small firms claim that the worst payers were large businesses.

Despite the obvious importance of trade credit and its risks, UK companies' working capital management practices tend to prioritise the management of inventories and cashflow budgeting (Paul, 2004; Peel et al., 2000; Wilson et al., 1999; Peel and Wilson, 1996; Dodge et al., 1994; Kargar and Blumenthal, 1994). Consequently, UK firms' inventory levels have been decreasing whilst debtors have nearly doubled over the last decade (Paul and Wilson, 2006; Pike and Cheng, 1996). The scale of the trade credit risks to SMEs suggests that they would be well advised to focus more on this issue.

Thus, whilst trade credit generally is a significant and complex socio-economic issue, it is a particular and current area of risk for SMEs. In this paper we explore and analyse the issue of late payment of SMEs with a view to furthering our understanding of its causes and possible remedies, using both the available literature and original empirical data from the UK. In doing so, we aim to progress beyond the measurement or testing of individual firm behaviour to consider trade credit as a complex and dynamic socio-economic system.

Our argument is that SMEs are incentivised, or perhaps even pressurised, into granting trade credit in order to be competitive. However, failures in both the regulatory environment and in management contribute to the scale and nature of the late payment problems experienced. We consider how these failings might be productively addressed. Accordingly, in section 2 we explain, by reference to the literature, the demand and supply factors that incentivise SMEs to offer trade credit. In section 3 we use our own empirical data to discuss two possible reasons for SMEs' difficulties in this area: regulatory failure and management issues. This is followed, in section 4 , by a discussion of the ways in which trade debt might be managed more strategically and successfully by SMEs. Whilst we explore this issue primarily by reference to the UK, it is likely that the nature of these problems is similar in all developed economies.

\section{Motivations, contexts and practices}

The fact that the extension of trade credit represents an inherent risk to SMEs begs the question as to why firms offer it: intuitively, suppliers would always demand immediate payment. The motivations are complex and multi-faceted, but can be broadly categorised into operational/business environment factors that generate demand and business advantages that may compensate for the risks and hence provoke supply.

Economic conditions, capital availability and the industry sector/market in which firms operate all influence trade credit decisions. For instance, fast growing firms or those operating in competitive markets are more likely to offer additional credit to extend their market share; in turn, they might be expected to demand more credit from their suppliers to create equilibrium in their cash conversion cycle. Similarly, seasonal businesses tend to demand more credit to deal with uncertain cashflow patterns (Paul, 2004; Wilson and Summers, 2002; Emery, 1987). Recession and other periods of financial distress may lead to increased demand for trade credit. Finally, firms with longer production cycles or substantial inventories, such as manufacturers, may have 
greater need for trade credit, pushing it up the pecking order (Summers and Wilson, 1999, 1997). If trade credit becomes a crucial factor in the business environment then suppliers may have little option but to respond positively to the demand.

Perhaps more intriguingly, extending trade credit may offer a number of more subtle competitive advantages to suppliers, including enhanced information on customers, reduced transaction costs, the ability to discriminate between customers in terms of price, reliable financing, and marketing and customer relations. We now deal with each in turn.

\section{Enhanced information}

To make sales decisions with confidence, sellers need reliable information about customers' creditworthiness, who in turn need information about the quality of suppliers' goods[1]. Trade credit can facilitate information flows by giving buyers time to investigate and assess the quality of the product before paying (Lee and Stowe, 1993; Long et al., 1993; Smith, 1987; Emery, 1984; Schwartz, 1974). Buyers may choose suppliers who offer credit as this is a signal of confidence in product quality and of long-term market presence, therefore acting as an implicit warranty (Paul and Boden, 2008; Paul and Wilson, 2006; Petersen and Rajan, 1997; Biais and Gollier, 1997; Smith and Schnucker, 1993; Lee and Stowe, 1993; Mian and Smith, 1992; Smith, 1987). Sellers who extend trade credit can use it to gather valuable information about customers' financial health through their payment patterns and their ability to take advantage of any discounts proffered for early payment (Paul and Boden, 2008).

\section{Reduced transaction costs}

The supply and financing of goods from a single source, utilising trade credit, can reduce transaction costs (Mian and Smith, 1992) in three principal ways. First, customers can be invoiced at regular intervals rather than after each order, reducing cash handling costs (Petersen and Rajan, 1997; Smith, 1987; Ferris, 1981). Second, it can reduce treasury costs by improving cashflow management: enhanced information about when customers are likely to settle can lead to better forecasting and a reduced need to carry expensive precautionary cash balances (Pike and Cheng, 1996). Third, in cash-based businesses with variable flows of receipts, trade credit can improve predictability by regularising payment patterns (Summers and Wilson, 1999).

\section{Pricing}

By varying trade credit terms, suppliers can manipulate prices offered to different customers in response to fluctuations in demand. It is much easier, and more subtle, to adjust the effective price by using the payment period than by changing the headline price (Petersen and Rajan, 1997; Mian and Smith, 1992; Schwartz and Whitcomb, 1978; Meltzer, 1960).

An important distinction must be drawn between offering credit terms and enforcing them. For instance, suppliers may allow a customer to pay after the agreed date without penalty, vary their two-part-terms (the discount for early payment) and offer higher discount rates to selected customers or even allow them to take unearned discounts. The way in which trade credit terms are enforced can, therefore, effectively reduce the price (Petersen and Rajan, 1997; Crawford, 1992; Schwartz and Whitcomb, 1978; Schwartz, 1974). 
JSBED

18,4

736
Reliable financing

The difficulties that small UK businesses face in obtaining funds from financial institutions have been well researched. Wilson et al. (1999) found that the provision of credit to small companies is widely recognised as enabling SMEs to start-up and grow successfully. Conversely, Bickers (1994) argues that a major contributory factor in growth constraint, cashflow problems and premature business failure is under-capitalisation leading to reliance on short-term finance.

Trade credit may alleviate financing problems by supplanting lending institutions: firms rationed by financial institutions for reasons of size, reputation, the nature of their assets and products or, indeed, prevailing economic conditions tend to turn to trade credit as a relatively cheap source of short-term funds (Atanasova and Wilson, 2004). Fraser (2008) finds that, between 2005 and 2008, over 37 per cent of SMEs used trade credit in this way, making this the third most popular external source of finance after credit cards (54 per cent) and bank overdrafts (42 per cent). Cosh et al. (2008) report that around 20 per cent of SMEs successfully negotiated an increase credit limits from their suppliers.

Trade credit is often seen as a free source of finance unless a discount for prompt payment is offered. Delaying payment may allow the buyer to earn interest on the funds or avoid borrowing costs (Summers and Wilson, 1998). Consequently, financially sound suppliers with relatively easy access to external funds or significant cash reserves tend to play an intermediary role, financing their customers through trade credit (Wilson and Summers, 2002; Petersen and Rajan, 1997; Elliehausen and Wolken, 1993; Chant and Walker, 1988; Emery, 1987, 1984; Schwartz, 1974). However, a price premium may be built in to take account of the time value of money.

Such financing functions can be mutually beneficial: plainly a demand exists for trade credit and, at the same time, its extension can amount to sound business practice if it assists in the growth of SMEs as part of a firm's customer base.

\section{Marketing and customer relations}

Small, new and growing firms may not have the same image, reputation, creditworthiness or borrowing power as large, well established and stable companies (Paul, 2004). Trade credit gives them the opportunity to demonstrate their capabilities both as suppliers, through their credit terms, and as customers via their payment behaviour. Negotiating trade credit provides opportunities for personal contact and the ability to indirectly obtain information about customers' creditworthiness.

Trade credit can be used to win market share (Paul and Wilson, 2007). Certain industry-specific customers (e.g. in manufacturing) and their suppliers are locked together by the speciality of the goods bought/sold. Such customers may be incentivised to comply with the contract through special credit terms, which also give them enough time to ascertain the quality of the goods prior to paying (Wilson and Summers, 2002; Ng et al., 1999; Smith, 1987).

Trade credit is obviously a response to a complex set of customer demands and also offers a number of strategic advantages in winning market share. Yet it is Janus faced: its extension also harbours substantial risks, especially for SMEs. In the next section we consider the reasons why trade credit becomes dysfunctional. 


\section{What is the problem?}

Despite these significant advantages, the market for trade credit has become problematic for UK SMEs. Like any market dysfunction, there are two, not necessarily mutually exclusive, ways of tackling the issue. One is to provide a voluntary or statutory regulatory framework. Such regimes can either impose legal sanctions (such as punitive interest) or give effect to voluntary codes of conduct. The other is for suppliers to alter their behaviour. In this section we first describe the regulatory regimes in place in the UK and discuss their effectiveness. We then explore SMEs' trade credit management practices and suggest how these might be improved.

The empirical data in this section comes from a structured questionnaire posted to firms randomly selected using Creditscorer, a reputable and established credit reference agency. When matched with the relevant financial information, the questionnaire results provided comprehensive and rich data. The survey was conducted in two tranches, the first to SMEs and the second to larger firms. The latter work is ongoing and is drawn upon in this paper in only a limited way for purposes of useful comparison. We conducted $t$-tests for late respondents and non-respondents and found that late respondents displayed characteristics similar to those who responded within the time limit. This supports the assumption that the non-respondents would have displayed similar characteristics to respondents. Consequently, this gives us confidence that the sample is not subject to a response bias.

Using the standard UK classification of firm size by number of employees (Table I), we sent the questionnaire to 1043 UK SMEs. This elicited 188 usable responses - an acceptable response rate of 18 per cent that compares favourably with previous similar studies of 16 per cent (Wilson et al., 1995) and 17.50 per cent (Howorth and Westhead, 2003). We then surveyed 1,467 larger firms and so far received 167 usable responses.

\section{Regulatory/statutory regimes}

In the 1990s in the UK and EU there was much heated debate about the desirability of legislation to tackle late payment. The European Commission was committed to the imposition of a statutory right to interest in cross border trade between member states and introduced legislation to this effect in 2002. In the UK, the Conservative government in power until 1997 favoured self-regulation over legislation, including measures such as British Standard BS7890 (a prompt payment code), training in financial and credit management and the disclosure of payment policies and practices in companies' financial reports. The government amended the Companies Acts in 1996 and 1997 to require UK public limited companies and large companies to disclose their payment policies and the average number of days taken to pay creditors.

From 1997 the new Labour government, in contrast, enacted a series of Commercial Debts (Interest) Acts that introduced a statutory right to interest on late payment. In 1998 SMEs were given the right to charge large companies and public sector

\begin{tabular}{lc}
\hline Size & $\%$ Firms \\
\hline Micro $(<10)$ & 22 \\
Small $(10-49)$ & 42 \\
Medium $(50-249)$ & 36 \\
Total & 100
\end{tabular}

Table I.

SME respondents by number of employees 
JSBED

18,4

738 organisations interest on late payments. The 2000 Act extended these rights to late payments between SMEs and then, in 2002, the right to statutory interest was extended to all firms. Under these successive Acts, creditors can charge interest at up to 8 per cent over the standard bank rate.

Late payment was seen as a major "contributory factor to small businesses' financial distress and failure and hampered growth and innovation" (Wilson, 2008, p. 10) and the intention of the legislation was that "it would make companies pay within the agreed terms and possibly change payment behaviour by creating a level 'paying' (!) field" (Paul, 2004, p. 81). Peel et al. (2000, p. 33) reported that SMEs surveyed in 1996, prior to the legislation, "considered the introduction of statutory penalties to curb late payment the most important factor associated with improving the performance of their business" and were optimistic about the legislation's potential. These laws were accompanied with other measures such as the establishment of the Best Practice Group on late payment, a British Standard for Payment, a Voluntary Code of Practice and calls the for the "naming and shaming" of late payers.

Such efforts have yielded only thin results. Between 1999 and 2004 the number of firms using the legislation was consistently low. In 1999 only 2 per cent of SMEs claimed to have used their statutory interest rights, while 30 per cent said they were not sure about it and wary of jeopardising customer relationships (CMRC, 2005). By 2002, although 79 per cent of firms were aware of the different phases of the legislation, only 5 per cent of SMEs used it (Wilson, 2008).

The weak effect of the legislation is signalled by the government's rediscovery of voluntary regulation: in December 2008 Lord Mandelson, then Secretary of State for Business, Enterprise and Regulatory Reform, announced a new code on late payment (ICM). As firms try to survive the escalating economic downturn, this code has been criticised, with many convinced that it "would not turn the tide of late payment" (The Financial Times, 2008), especially when the "victims" are small firms. The combination of a worsening late payment problem over the past decade and the failure to take up the possibilities offered by the statutory interest legislation clearly suggests that the legislative approach has failed to change payment behaviour.

Our data shows that most SMEs do not expect the legislation to make any difference to their customers' payment patterns: only 24 per cent think the legislation may help. It is therefore unsurprising that only 31 per cent of our respondents make their customers aware of their rights to charge interest. We found a positive correlation between credit terms that mention interest charges and firm size: larger firms are more likely to include these statements in their credit terms than smaller ones are. The Spearman's rho correlation coefficient is 0.162 and significant at 5 per cent level. This is reflected in the fact that 81 per cent of the respondents have "never" or "rarely" charged interest on late payments and, of those that communicate their right to charge interest, only 7 per cent of them are actually willing to charge it on overdue accounts. Despite this, 55 per cent see bad debts from domestic customers as a "very serious" or a "serious" problem. These findings are consistent with previous research (e.g. CMRC, 2002).

Suppliers may fear losing sales if they charge statutory interest more than late payment Wilson (2008). Indeed, Howorth and Wetherhill (2000) found that suppliers were less likely to charge penalty interest on late payment where relationships with customers were considered important. Our respondents cited the possible adverse effect on customer relations as the main reason for not charging interest. Lesser 
reasons cited included administrative burdens and other costs. Respondents claimed that large businesses were the worst late payment offenders: 44 per cent of respondents were "very often" or "always" paid late by larger customers. This suggests that less powerful SMEs may, despite legislative regimes, have little effective power.

This evidence points to the continuing failure of formal regulatory regimes in helping SMEs tackle late payment issues, suggesting that even more rigorous regimes are unlikely to have very much or any effect unless these underlying issues of business power are addressed.

\section{Credit management failures}

Many firms fail because of poor credit management (Perrin, 1998; Summers and Wilson, 2000) and it is evident that one of the main factors in late payment is the mismanagement of and passive role assigned to trade credit in organisations. The costs of managing late payment can erode profitability, especially when profit margins are tight (Paul, 2007). Unlike statutory interest provisions, firms have a significant degree of agency regarding the management of trade debtors. The data presented below suggests that most SMEs have failed to develop an appropriate and effective capacity in this regard, compounding the regulatory failures.

The extent of late payment can be gauged by measuring the average number of days beyond the stated due date that payment is received. More than 61 per cent of our respondents reported that late payment was a "serious" or "very serious" problem for their businesses. Table II shows just how late these late payers were.

Table III shows the days' sales outstanding (DSO - the average number of days that a company takes to collect revenue after a sale has been made) by respondent firm size. 54, 80 and 73.8 per cent of micro, small and median companies were paid, respectively, at least forty days beyond the normal payment term of 30 days. The longer a debt is outstanding, the higher the risk of default.

Further analysis was undertaken to see if the size of the respondent had a bearing on the extent of late payment, comparing SMEs with large firms. Our results are in line with previous studies: when size is expressed in terms of the number of employees, the larger the firms the fewer debtor days beyond the due date, although the difference is relatively small (Table IV). When comparing SMEs and larger firms, Wilson (2008)

\begin{tabular}{lccccc}
\hline Days beyond due date: & 1 to 14 & 15 to 29 & 30 to 59 & Over 60 & Table II. \\
Percentage of firms: & 37.2 & 32.4 & 20.9 & 9.5 & Payment beyond due date \\
\hline
\end{tabular}

\begin{tabular}{|c|c|c|c|c|}
\hline \multirow[b]{2}{*}{ DSO } & \multicolumn{3}{|c|}{ Percent by firm size (number of employees) } & \\
\hline & $<10$ & $10-49$ & $50-249$ & \\
\hline $1-7$ & 7.7 & 0 & 4.8 & \\
\hline $8-14$ & 23 & 0 & 0 & \\
\hline $15-21$ & 0 & 0 & 7.1 & \\
\hline $21-30$ & 7.7 & 4 & 4.8 & Table III. \\
\hline $31-40$ & 7.7 & 16 & 9.5 & Days sales outstanding \\
\hline$>40$ & 54 & 80 & 73.8 & (DSO) \\
\hline
\end{tabular}

\section{Size matters}

739

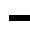


JSBED

18,4

740

reports that between 2000 and 2007 SMEs took between 58-61 days to pay whilst their larger counterparts took between 74-81 days to pay.

However, when size is expressed in terms of turnover, the difference is striking: firms with an annual turnover of $>£ 50 \mathrm{~m}$ have an average DSO of 11 days, therefore paying significantly faster than those with a turnover of between $£ 10 \mathrm{~m}$ and $£ 19.9 \mathrm{~m}$ (Table V). Similarly, Wilson (2008) found that between 1997 and 2007, 50 per cent of invoices were paid late, with small firms experiencing a delay of 22 days as against 8 days for large ones.

There is widespread agreement amongst researchers that companies should have clear policies to manage the granting of credit to mitigate the risk of delayed payment or default (Summers and Wilson, 2000). Firms benefit from a "formal credit policy to guide the day-to-day micromanagement of individual buyer accounts" (Wells, 2004, p. 4) and help provide consistent credit decisions (Christie and Bracuti, 1981). Wilson et al. (1995) see such policies as part of corporate strategy and Pike et al. (1998) consider them an important link in organisations' communication chains.

Bass (1991) asserts that every company should have a credit policy that is clearly articulated, communicated and understood by everyone involved in the process of giving credit including customers. Similarly, Mudge (1999) argues that it is essential for trade credit policies to be both clearly formulated and documented, with specific instructions and communicated at every level and at each stage of transactions. Wilson et al. (1995) argue that credit policies should be used "as part of the marketing mix or as a means of building stable and long-term relationships with customers and suppliers" (Wilson et al., 1995, p. 4).

Despite this, fewer than half (46.8 per cent) of our respondents had a written credit policy. Wilson (2008) found similar measures of 26 per cent in 1996, and 46 per cent in 2004. We found a correlation between firm size and written credit policy: SMEs are less likely to have one compared to their larger counterparts. Further, our respondents showed a greater propensity to deal with issues around assigning responsibility rather than the setting of performance objectives or, indeed, training (Table VI).

The importance attached to the credit function can, we suggest, be gauged by using the investment made in the staff running it as a proxy. Unsurprisingly, our data reveal the numbers of staff engaged in credit management was in direct proportion to firm size and over 72 per cent of the firms had no staff just one person working on this. Only 11 per cent of the credit managers within the sample are member of the Institute for Credit Management, suggesting a low degree of professionalisation.

Table IV.

Employee size band

$<10$

$10-49$

$50-249$

Size, average debtor days offered and average DSO

Average debtor days offered

43.1

46.3

24.3

48.5

Average DSO

\begin{tabular}{lccccccr}
$\begin{array}{l}\text { Size } \\
\text { Turnover }(£ \mathrm{~m})\end{array}$ & $<1$ & $1-2.4$ & $2.5-4.9$ & $5-9.9$ & $10-19.9$ & $20-49.9$ & $>50$ \\
\hline Average DSO & 25.5 & 24.4 & 16.0 & 19.5 & 29.5 & 20.8 & 11.0
\end{tabular}

Table V.

Comparison of average DSO by firm size (turnover)

Average DSO

23.2

24.3

\begin{tabular}{cr} 
& 22.2 \\
\hline & \\
& \\
\hline $20-49.9$ & $>50$ \\
\hline 20.8 & 11.0 \\
\hline
\end{tabular}


Our results show that credit staff spent most of their time on back-end activities, such as chasing late payment, despite the evident importance of the front-end operations such as customer risk assessment. As might be expected, those that spend more effort at the front-end reduce the time spent on collection activities and resolving disputed billing.

We analysed time spent on different credit activities by firm size. Firms that address credit management proactively, such as evaluating credit risks and establishing payment terms and methods, experience a concomitant reduction in time spent on collection activities and resolving disputed billing (Table VII).

Micro firms (mainly owner-managed) expend a lot of effort on front-end activities compared with other respondents - perhaps because their levels of exposure from single customers makes them more risk averse and hence they invest in work such as checking customers' creditworthiness and negotiating payment terms. Their smaller scale may mean that there has to be less formalisation and a more "personal" approach.

It has been argued that late payment problems are exacerbated by the fact that firms, especially small ones, do not send invoices or statements on time, or in some cases, at all. Our results show (Table VIII) that micro firms tend to bill more promptly than small and medium enterprises. This is not surprising given that small firms' survival may depend on getting the cash into the company as quickly as possible. Nor is it surprising that larger firms also tend to have better credit management practices this possibly reflects that these are well-managed firms that have survived and thrived. There is something of the "missing middle" here - firms too large to be driven by the imperative of needing immediate payment, but too small to embed more professional management practices.

Overall, our data shows that SMEs generally have quite poor trade credit management practices, despite their acknowledgement of the seriousness of this issue.

\begin{tabular}{|c|c|c|c|}
\hline & Percent "Yes" & Percent "No" & \\
\hline $\begin{array}{l}\text { Firms with a written credit policy } \\
\text { Of firms with written credit bolicy does it define. }\end{array}$ & 46.8 & 53.2 & \\
\hline Responsibility for different credit tasks? & 84.2 & 15.8 & \\
\hline payments? & 89.5 & 10.5 & \\
\hline Timetable for action and intervals for collection? & 83.1 & 16.9 & \\
\hline Performance objectives? & 54.1 & 45.9 & Table VI. \\
\hline Training for credit manager and credit staff? & 75.7 & 24.3 & Written credit policies \\
\hline
\end{tabular}

\begin{tabular}{|c|c|c|c|c|}
\hline Size & $\begin{array}{l}\text { Monitoring cash-flows/ } \\
\text { resolving disputed } \\
\text { billings }\end{array}$ & Back-end activities & Front-end activities & \\
\hline$<10$ & 18 & 40 & 42 & Table VII. \\
\hline $10-49$ & 23 & 52 & 26 & Percentage of time spent \\
\hline $50-249$ & 23 & 54 & 24 & on credit management by \\
\hline$\geq 250$ & 24 & 46 & 30 & firm size \\
\hline
\end{tabular}


JSBED

18,4

\section{2}

SMEs suffer more late payment than larger firms, have weak trade credit policies, and employ few staff to deal with trade credit management.

\section{What is to be done?}

In this paper we demonstrate why, despite the risk, UK SMEs offer trade credit. Yet regulatory and management failures escalate the risks of trade credit supply. We now consider how these risks might be mitigated whilst meeting demand for trade credit and taking advantage of the competitive opportunities it can provide.

Lord Mandelson, when he was Secretary of State for Business, Enterprise and Regulatory Reform, argued that the new voluntary prompt payment code launched in December 2008 would be vital to small firms' survival (Rileycom, available at: www. rileycom.co.uk/rileycom \% 5Cdata \% 5Cdocument.nsf/ID/25DE0BC7CD7821E38025751 D00422F9A?OpenDocument; accessed 30 November, 2009.). However, the evidence in this paper suggests that current regulatory regimes, of whatever nature, are unlikely to resolve the problems because of the power balance in trading relationships. Wilson regards late payment "as a problem caused by large companies exploiting dominant positions in competitive chains” (Wilson, 2008, p. 10). SMEs, as our data suggests, are significantly disadvantaged in exercising their rights against larger firms. Voluntary regimes appear to have had little impact on customer compliance and, we posit, this situation is likely to be aggravated during the current global financial downturn. That said, there may be scope for a thorough evaluation of regulatory (both voluntary and legislative) regimes globally and, perhaps, serious work on re-thinking how these might be constructed so as to be more effective. This is beyond the scope of this paper.

If resolution of this issue is unlikely to come through regulatory regimes, either voluntary or statutory, then SMEs must put their own houses in order by instituting more effective regimes of credit management. In their study of SMEs, Howorth and Wilson (1999) identify two sorts of firms: those who suffer from late payment and those who control it. The problem of late payment cannot "be totally eliminated since payment behaviour is, to some extent, a function of a firm's financial health and management professionalism" (Wilson, 2008, p. 12). Improvements in trade credit management can, we suggest, be conceived as having four aspects: policies, people, processes and practices. We deal with each in turn.

\section{Policies}

Wilson finds "those firms with less of a problem were more likely to have a credit policy" (Wilson, 2008, p. 106). Despite evidence suggesting the importance of written trade credit policies, just under half of our SME respondents had one. Whilst this

\begin{tabular}{lcccc}
\hline Size (number of employees) & $<10$ & $10-49$ & $50-249$ & $>250$ \\
\hline Before dispatch & 07.7 & 01.3 & 01.6 & 03.8 \\
Immediately & 43.6 & 35.6 & 27.0 & 34.7 \\
Within 3 days & 25.6 & 32.9 & 47.6 & 42.3 \\
4-7 days & 15.4 & 28.9 & 19.0 & 11.5 \\
8-14 days & 02.6 & 01.3 & 01.6 & 01.9 \\
$>$ 14 days & 05.1 & 00.0 & 03.2 & 05.8 \\
\hline
\end{tabular}

Table VIII.

Time lag between dispatch and invoice by firm size 
should clearly be a priority area for SMEs, policies need to be formulated and articulated with care. A good trade policy reflects a nuanced balance between endogenous and exogenous influences on the firm. Kaplan (1967) was an early advocate of credit policy as a promotional rather than purely financial tool. Wilson et al. (1995) argue that credit policy needs to be tailored to the needs of the market that it serves. Pike et al. (1998) reinforce the importance of credit formulation but also of the impact of the external environment, emphasising that an understanding of the competitive position was a necessary precursor to developing a trade credit policy. More strongly still, Mian and Smith (1992) emphasise the central importance of the systematic economic forces that drive trade credit policy decisions. Moreover, as companies operate in a dynamic environment, proactive credit management is necessary to cope with constant change to adapt to market and economic conditions. A well-documented credit policy should therefore permit change, flexibility and adaptability.

\section{People}

Peel and Wilson (1996) argue that firms can make proactive use of trade credit policies to prevent rather than cure the problem of late payment. This, they argue, can be achieved by involving credit managers in the "front-end activity of negotiating, risk-screening, using credit information and establishing clear credit policies" (Peel and Wilson, 1996, p. 20), rather than giving them a passive role. In the same vein, Wilson finds that firms that "spent more time on "front-end" credit management" suffer less from late payment (Wilson, 2008, p. 106). Wells speculates that "credit executives will soon be recognised as having an important contribution to make as the strategic managers of the significant investment in accounts receivable, and of the risk profile of that investment" (Wells, 2004, p. 60). Such an approach departs from the traditional view of credit as a department involved mainly at the back-end of the sales process.

Our data suggests that our respondent SMEs paid little attention to the specialised staffing of the credit management function. This is perhaps understandable for micro businesses, where the owners will often undertake all work themselves - yet here the balance of activity was towards the front-end. But in small and medium enterprises most staff spent the majority of their time on back-end rather than front end activities, working in a responsive rather than a proactive role. This, we argue, reduces firms' capacities for the strategic use of trade credit.

\section{Process}

$\mathrm{Ng}$ et al. (1999, p. 1111) argue that "credit policy is an organisational design choice to internalise activities as opposed to relying on the market". Wilson et al. (1995) report that companies without credit policies, whose credit terms were ad hoc responses to customer demands, spent more time negotiating credit terms. This is likely to increase transaction costs and reduce corporate ability to use trade credit to strategic advantage.

Firms need robust and reliable processes to assess risk and decide whether to extend credit. The optimal balance between loosing a sale and selling to a customer who may delay payment or default is not easy to strike. Expertise in and knowledge of the credit management function and customer base are therefore vital to good decision making. Once trade credit has been granted, predicted patterns of payments help 
JSBED

18,4

\section{4}

companies forecast their liquidity position. SMEs need to "copy" larger firms who "take more care to categorise customer risk and implement better credit control and payment methods and it is these arrangements that give rise to more prompt payment for the customer base" (Wilson, 2008, p. 107).

\section{Practices}

Once policies and people are in place and processes established, SMEs need to ensure that they determine their actual practice. Paul and Wilson (2006) argue that ad hoc credit management is very inefficient. Peel et al. (2000) point out that enforcement of credit terms can be a problem, especially for small firms. Graydon, credit management professionals, claim that imaginative and proactive practice can be extremely effective (The Financial Times, 2007). Howorth and Wilson found that those that who suffer the most from late payment "had poor credit management practices" (Howorth and Wilson, 1999, p. 314). Similarly, Wilson posits that "SMEs that had adopted sound credit management practices' found late payment less of a problem" and "education in financial and credit management practices would do more to reduce late payment problems than other interventions" (Wilson, 2008, p. 106).

Credit insurance may be a sound option for SMEs: it can transfer risks and reduce earnings uncertainty (Wilson, 2008). It also provides some related services such as: "continuous monitoring of creditworthiness of the insured's customers, maintaining account receivables, suggesting payment and delivery conditions and supporting debtors collection" (Wilson, 2008, p. 149). Wilson argues that it enhances access to finance, as firms with credit insurance may get better terms from banks because the value of debtors is used as collateral.

Power balances are crucial in the practice of effective trade credit management, and this may be the biggest and perhaps most insurmountable of hurdles for SMEs. As Howorth and Wilson (1999, p. 308) put it: "the popular view is that late payment arises from customers who are dominant in relation to their suppliers exercising market power and obtaining a cheap form of finance, the latter being powerless to impose sanctions'. The current poor prospects for the economy suggest that trade credit issues may become even more important for SMEs and it is, perhaps, time for a rather more proactive approach within the regulatory regime, enabling trade credit to be, in turn, more effectively managed.

\section{Note}

1. We use "goods" to mean products and services

\section{References}

Atanasova, C.V. and Wilson, N. (2004), "Disequilibrium in the UK corporate loan market", Journal of Banking and Finance, Vol. 20 No. 3, pp. 595-614.

Bass, R.M.V. (1991), Credit Management: How to Manage Credit Effectively and Make a Real Contribution to Profit, 3rd ed., Stanley Thornes, Cheltenham.

Biais, B. and Gollier, C. (1997), "Trade credit and credit rationing”, Review of Financial Studies, Vol. 10 No. 4, pp. 903-37.

Bickers, M. (1994), "Factoring an industry of last resort”, Director, Vol. 47 No. 6, pp. 43-8. 
Chant, E.M. and Walker, D.A. (1988), "Trade credit and monetary policy”, Applied Economics, Vol. 20, pp. 861-76.

Chittenden, F. and Bragg, R. (1997), "Trade credit, cash-flow and SMEs in the UK, Germany and France”, International Small Business Journal, Vol. 16, pp. 22-35.

Christie, G.N. and Bracuti, A.E. (1981), Credit Management, Credit Research Foundation, Columbia, MD.

CMRC (2002), Credit Management Quarterly Review, Leeds University, Leeds.

CMRC (2005), Credit Management Quarterly Review, Leeds University, Leeds.

CMRC (2006), Credit Management Quarterly Review, Leeds University, Leeds.

Crawford, P. (1992), “A survey of the trade credit literature”, Discussion Paper No 92/324, Department of Economics, University of Bristol, Bristol.

Cosh, A., Hughes, A., Bullock, A., Milner, I. and Financing, U.K. (2008), "Financing UK small and medium sized enterprises" The 2007 Survey, Centre for Business Research, Cambridge University, Cambridge, August.

Dodge, H., Fullerton, S. and Robbins, J. (1994), "Stage of the organisational life cycle and competition as mediators of problem perception for small businesses", Strategic Management Journal, Vol. 15, pp. 121-34.

Elliehausen, G.E. and Wolken, J.D. (1993), "The demand for trade credit: an investigation of motives for trade credit use by small businesses", Federal Reserve Bulletin, Paper 165.

Emery, G. (1984), “A pure financial explanation for trade credit”, Journal of Financial and Quantitative Analysis, Vol. 19 No. 3, pp. 271-85.

Emery, G.W. (1987), "An optimal explanation for trade credit”, Journal of Financial and Quantitative Analysis, Vol. 22 No. 2, pp. 209-25.

Europa (2009), Combating Late Payment: The Economic Rationale, available at: http://ec.europa. eu/enterprise/regulation/late_payments/rationale.htm (accessed 12 October, 2009).

Ferris, J.S. (1981), “A transaction theory of trade credit use”, The Quarterly Journal of Economics, Vol. 96, pp. 243-70.

Forum of Private Business (2008), available at: www.fpb.org/news/2091/Research_shows_ payment_pain_getting_worse.htm (accessed 30 November, 2009).

Fraser, S. (2008), "Small firms in the credit crisis: evidence from the UK survey of SME finances", United Kingdom Survey of Small- and Medium-Sized Enterprises' Finances, available at: www2.warwick.ac.uk/fac/soc/wbs/research/csme/research/latest/small_firms_in_the_ credit_crisis_v3-oct09.pdf (accessed 1 December, 2009).

Howorth, C. and Wilson, N. (1999), "Late payment and small firms: an examination of case studies", Journal of Small Business and Enterprise Development, Vol. 5 No. 4, pp. 307-15.

Howorth, C. and Wetherhill, P. (2000), "Relationship between large and small companies and the impact of UK late payment legislation", Proceedings of the 22nd National Small Firms Policy and Research Conference, Institute of Small Business Affairs, Leeds.

Howorth, C. and Westhead, P. (2003), "The focus of working capital management in UK small firms", Management Accounting Research, Vol. 14 No. 2, pp. 94-111.

Kaplan, R.M. (1967), "New technique for optimising - credit risks and opportunities", Harvest Business Review, Vol. 65 No. 2, pp. 83-8.

Kargar, J. and Blumenthal, R.A. (1994), "Leverage impact of working capital in small businesses”, TMA Journal, Vol. 14 No. 6, pp. 46-53.

Lee, Y.W. and Stowe, J.D. (1993), "Product risk, asymmetric information and trade credit", Journal of Finance and Qualitative Analysis, Vol. 28 No. 2, pp. 285-300. 
JSBED

18,4
Long, M.S., Malitz, I.B. and Ravid, S.A. (1993), "Trade credit, quality guarantees and product marketability", Financial Management, Vol. 22 No. 4, pp. 117-27.

Manager (2009), “Late payments to SMEs leap 40\% to £256 billion”, Manager, Spring, p. 8.

Meltzer, A.H. (1960), "Mercantile credit, monetary policy and size of firms", Review of Economics and Statistics, Vol. 42, pp. 429-37.

Mian, S.L. and Smith, C.W. (1992), "Accounts receivable management policy: theory and evidence”, Journal of Finance, Vol. 47 No. 1, pp. 169-200.

Mugde, P. (1999), "Foreword", Credit Management, April 27.

Ng, C.K., Smith, J.K. and Smith, R.L. (1999), "Evidence on the determinants of credit terms used in interfirm trade", Journal of Finance, Vol. 54 No. 3, pp. 1109-29.

Paul, S.Y. and Boden, R. (2008), "The secret life of UK trade credit supply: setting a new research agenda", The British Accounting Review, Vol. 40 No. 3, pp. 272-81.

Paul, S.Y. (2007), "Trade credit management and the late payment problem: empirical evidence", Credit Management, January, pp. 26-9.

Paul, S.Y. and Wilson, N. (2007), "Trade credit supply: an empirical investigation of companies level data", Journal of Accounting, Business and Management, Vol. 13, pp. 83-113.

Paul, S.Y. and Wilson, N. (2006), "The determinants of trade credit demand: survey evidence and empirical analysis", Journal of Accounting Business and Management, Vol. 14, pp. 96-116.

Paul, S.Y. (2004), "Strategic trade credit: an empirical study", $\mathrm{PhD}$ thesis, Leeds University Business School, Leeds.

Peel, M.J., Wilson, N. and Howorth, C. (2000), "Late payment and credit management in the small firm sector: empirical evidence", International Small Business Journal, Vol. 18 No. 2, pp. 17-37.

Peel, M.J. and Wilson, N. (1996), "Working capital and financial management practices in the small firm sector", International Small Business Journal, Vol. 14 No. 2, pp. 52-68.

Perrin, S. (1998), "Credit control is power: techniques for efficient credit-control for small and medium sized companies", Management Today, 1 February, pp. 78-9.

Petersen, M.A. and Rajan, R.G. (1997), "Trade credit: theories and evidence”, Review of Financial Studies, Vol. 10 No. 3, pp. 661-91.

Pike, R.H. and Cheng, N.S. (2001), "Credit management: an examination of policy choices, practices and late payment in UK companies", Journal of Business Finance and Accounting, Vol. 28, pp. 1013-42.

Pike, R.H., Cheng, N.S. and Chadwick, L. (1998), Managing Trade Credit for Competitive Advantage: A Study of Large UK Companies, CIMA Publishing, London.

Pike, R.H. and Cheng, N.S. (1996), "Business trade credit management: experience of large UK firm", Proceedings of the British Accounting Association Conference, April.

Schwartz, R.A. (1974), "An economic model of trade credit", Journal of Finance and Quantitative Analysis, Vol. 9, pp. 643-57.

Schwartz, R.A. and Whitcomb, D.K. (1978), "Implicit transfers in the extension of trade credit", in Boulding, K.E. and Wilson, T.F. (Eds), Redistribution through the Financial System: The Grants Economics of Money and Credit, Praeger Special Studies, Boulding, NY.

Smith, J.K. and Schnucker, C. (1993), "An empirical examination of organisational structure: the economics of factoring decision”, Journal of Corporate Finance, Vol. 1 No. 1, pp. 119-38.

Smith, J.K. (1987), "Trade credit and information asymmetry”, Journal of Finance, Vol. 62 No. 4, pp. 863-72.

Summers, B. and Wilson, N. (2000), "Some empirical evidence on late payment in the UK", Credit Management, 8 July. 
Summers, B. and Wilson, N. (1999), “An empirical investigation of trade credit extension”, paper presented at the Eleventh Annual PACAP/FMA Finance Conference, Singapore, July.

Summers, B. and Wilson, N. (1998), Evidence on Determinants of the Trade Credit Period and Sales Terms Choices, CMRC, Leeds University Business School, Leeds.

Summers, B. and Wilson, N. (1997), "Influences on payment behaviour", Credit Management, September, pp. 27-9.

The Financial Times (2007), 13 January, available at: www.ft.com/cms/s/0/73648b4a-a2aa-11dba187-0000779e2340.html?nclick_check=1 (accessed on 14 July, 2009).

The Financial Times (2008), 12 December, available at: www.ft.com/cms/s/0/add5e4dc-c79b11dd-b611-000077b07658.html (accessed 18 July, 2009).

Wells, R. (2004), Global Credit Management: An Executive Summary, John Wiley Finance, Chichester.

Wilson, N. (2008), An Investigation into Payment Trends and Behaviour in the UK: 1997-2007, CMRC Centre, Leeds University Business School, Leeds.

Wilson, N. and Summers, B. (2002), "Trade credit terms offered by small firms: survey evidence and empirical analysis", Journal of Business Finance and Accounting, Vol. 29, pp. 317-51.

Wilson, N., Singleton, C. and Summers, B. (1999), "Small business demand for trade credit, credit rationing and late payment of commercial debts: an empirical study", in Wright, N. and Robbie, K. (Eds), Management Buy-outs and Venture Capital: Into the Next Millennium, Edward Elgar Publishing, Cheltenham.

Wilson, N., Watson, K., Singleton, C. and Summers, B. (1996), Credit Management, Late Payment and the SME Business Environment: A Survey, Credit Management Research Group, University of Bradford, Bradford.

Wilson, N., Watson, K. and Summers, B. (1995), "Trade relationships, credit management and corporate performance: a survey", CMRC Group, University of Bradford, Bradford.

\section{Further reading}

CMRC (1999), Credit Management Quarterly Review, Leeds University, Leeds.

CMRC (2000), Credit Management Quarterly Review, Leeds University, Leeds.

CMRC (2001), Credit Management Quarterly Review, Leeds University, Leeds.

\section{About the authors}

Salima Y. Paul is a Senior Lecturer in Accounting at Bristol Business School, University of the West of England, and has several published works on trade credit. Dr Paul is internationally renowned in the trade credit community for her work in this field, working closely with a number of professional bodies. Together with Rebecca Boden, she is currently engaged on an ACCA-funded qualitative project investigating the power relationships between SME suppliers and their larger customers. Salima Y. Paul is the corresponding author and can be contacted at: salima.paul@uwe.ac.uk

Rebecca Boden is a Professor of Critical Management at Roehampton Business School, Roehampton University. She has published extensively in the area of accounting and management and has a long-standing research interest in self-employed people and other micro-businesses.

\footnotetext{
To purchase reprints of this article please e-mail: reprints@emeraldinsight.com
} Or visit our web site for further details: www.emeraldinsight.com/reprints 